\title{
Spencer Ambrose Beach (1860-1922)
}

\author{
Michael H. Chaplin \\ Department of Horticulture, 106 Horticulture Hall, Iowa State University, Ames, IA 50011
}

What kind of a world would we have were it not for the dreamer, the seer, for him who sees visions and then goes to work to bring his visions to pass?

- S.A. BEACH

The legacy left by Spencer Ambrose Beach was assured by his prominence in the creation of ASHS; his classic two-volume work, Apples of New York (published in 1905); and his enthusiastic and tireless work toward furthering the knowledge of horticultural science through improved and winter-hardy plant cultivars. His scholarly contributions to horticultural development, research, and education created the field of modem horticultural science.

Born on 15 Sept. 1860 at Sumnerhill, N.Y., Beach's education began in the Cayuga County public schools. After grade school, he taught at a district school in Michigan before becoming a student at the academy in Homer, N.Y. He attended high school in Ann Arbor, Mich., then taught in the public schools of southeastern Iowa. It was at this juncture that he met pioneering horticulturists George O. Van Houten and J.L. Budd, head of the Horticulture Dept. at Iowa State College. Beach entered the college in 1884 and, under tie inspiring tutelage of Prof. Budd, selected horticulture as his life's work. After receiving his BS in 1887, Beach accepted a job with the Silas Wilson Nurseries in Athmtic, a small town in western Iowa. Over the next 3 years Beach sold nursery stock-often riding horseback or walking through many of the rural districts, where he learned firsthand about the farmer and his needs and challenges. He earned his MS in plant pathology from Iowa State College in 1892.

In 1891, after spending 1 year as head of the Horticulture Dept. at Texas A\&M, Beach joined the New York Experiment Station at Geneva, where he remained for 14 years. He is credited with establishing the first fruit breeding program at the station in 1898 . His cross of 'Ben Davis' apple with 'Macintosh' in 1915 resulted in the 'Cortland' apple, which is still

Received for publication 28 May 1993.

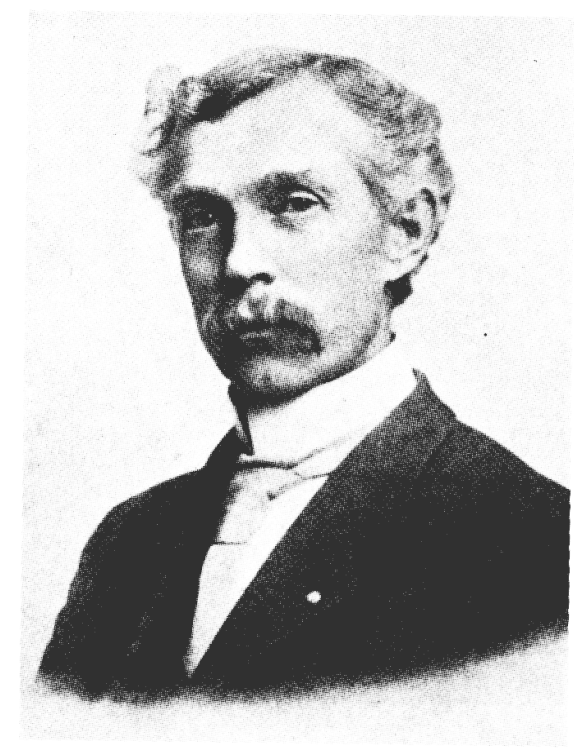

four MS degrees had been granted. In the 17 years that Beach headed the department, 74 $\mathrm{BS}$ and $26 \mathrm{MS}$ degrees in horticulture were granted. Beach also developed and taught a basic course in plant breeding that later led to the addition of a Genetics Dept. in the College of Agriculture. He was instrumental in securing a new horticulture building, which still serves as an integral part of the current horticulture facility at Iowa State Univ.

Beach had long been interested in the concept of using plant breeding to produce hardy cultivars for cold climates. While at Iowa, he introduced 11 winter-hardy apple cultivars between 1921 and 1922 for the upper Mississippi Valley and the Great Plains. Under his guidance, 'ibis region remained the major U.S. apple producer for more than 30 years, until the Armistice Day freeze of 1940, which killed the trees to the ground.

With his election as an honorary member of the Royal Horticultural Society of London in 1903, Beach became convinced that the United States needed an organization for professional horticulturists from the teachers and research scientists on staff at U.S. land-grant colleges and the U.S. Dept. of Agriculture. He became the prime mover in the creation of ASHS in Boston in 1903. During the Society's early critical years, he served as secretary and later as president. He used his forum to urge his own state (Iowa) and the nation to resist "individualism" at the expense of success in horticultural pursuits through cooperation.

At the time of his death in 1922, Beach's reputation as an insightful teacher, administrator, and leader, and as the creator of great and lasting contributions to horticultural development, research, and education was assured. To his contemporaries, Beach was considered a true gentleman-enthusiastic and forceful, yet quiet in demeanor and speecha humble, gracious individual; steadfast friend and trusted mentor; and a learned and inspiring teacher. A man of principle and high ideals, he believed the true purpose of his life was to serve others, and he did so untiringly within academia the community, and the nation to make great and lasting contributions to the advancement of horticultural science and, thus, to the quality of life of all people. 